\title{
Frequently increased epidermal growth factor receptor (EGFR)
} copy numbers and decreased BRCA I mRNA expression in Japanese triple-negative breast cancers

\author{
Tatsuya Toyama*1, Hiroko Yamashita ${ }^{1}$, Naoto Kondo ${ }^{1}$, Katsuhiro Okuda ${ }^{1}$, \\ Satoru Takahashi ${ }^{2}, 3$, Hidefumi Sasaki ${ }^{1}$, Hiroshi Sugiura ${ }^{1}$, Hirotaka Iwase ${ }^{4}$ and \\ Yoshitaka Fujii ${ }^{1}$
}

\begin{abstract}
Address: ${ }^{1}$ Department of Oncology, Immunology and Surgery, Nagoya City University Graduate School of Medical Sciences, 1 Kawasumi, Mizuhocho, Mizuho-ku, Nagoya 467-8601, Japan, ${ }^{2}$ Department of Experimental Pathology and Tumor Biology, Nagoya City University Graduate School of Medical Sciences, 1 Kawasumi, Mizuho-cho, Mizuho-ku, Nagoya 467-8601, Japan, ${ }^{3}$ Division of Pathology, Nagoya City University Hospital, 1 Kawasumi, Mizuho-cho, Mizuho-ku, Nagoya 467-8601, Japan and ${ }^{4}$ Department of Breast and Endocrine Surgery, Kumamoto University Graduate School of Medical Sciences, 1-1-1 Honjo, Kumamoto 860-8556, Japan

Email: Tatsuya Toyama* - toyamat-ncu@umin.ac.jp; Hiroko Yamashita - hirokoy@med.nagoya-cu.ac.jp; Naoto Kondo - nao0613@med.nagoya-cu.ac.jp; Katsuhiro Okuda - kokuda@med.nagoya-cu.ac.jp; Satoru Takahashi - sattak@med.nagoyacu.ac.jp; Hidefumi Sasaki - hisasaki@med.nagoya-cu.ac.jp; Hiroshi Sugiura - hsugiura@med.nagoya-cu.ac.jp; Hirotaka Iwase - hiwase@kumamoto-u.ac.jp; Yoshitaka Fujii - yosfujii@med.nagoya-cu.ac.jp

* Corresponding author
\end{abstract}

Published: 25 October 2008

BMC Cancer 2008, 8:309 doi:10.1 186/147/-2407-8-309
Received: 15 July 2008

Accepted: 25 October 2008

This article is available from: http://www.biomedcentral.com/I47/-2407/8/309

(C) 2008 Toyama et al; licensee BioMed Central Ltd.

This is an Open Access article distributed under the terms of the Creative Commons Attribution License (http://creativecommons.org/licenses/by/2.0), which permits unrestricted use, distribution, and reproduction in any medium, provided the original work is properly cited.

\begin{abstract}
Background: Triple-negative breast cancer (estrogen receptor-, progesterone receptor-, and HER2-negative) (TNBC) is a high risk breast cancer that lacks specific therapy targeting these proteins.

Methods: We studied 969 consecutive Japanese patients diagnosed with invasive breast cancer from January 198I to December 2003, and selected TNBCs based on the immunohistochemical data. Analyses of epidermal growth factor receptor (EGFR) gene mutations and amplification, and BRCAI mRNA expression were performed on these samples using TaqMan PCR assays. The prognostic significance of TNBCs was also explored. Median follow-up was 8.3 years.

Results: A total of 110 (II.3\%) patients had TNBCs in our series. Genotyping of the EGFR gene was performed to detect 14 known EGFR mutations, but none was identified. However, EGFR gene copy number was increased in $21 \%$ of TNBCs, while only $2 \%$ of ER- and PgR-positive, HER2negative tumors showed slightly increased EGFR gene copy numbers. Thirty-one percent of TNBCs stained positive for EGFR protein by immunohistochemistry. BRCAI mRNA expression was also decreased in TNBCs compared with controls. Triple negativity was significantly associated with grade 3 tumors, TP53 protein accumulation, and high Ki67 expression. TNBC patients had shorter disease-free survival than non-TNBC in node-negative breast cancers.
\end{abstract}

Conclusion: TNBCs have an aggressive clinical course, and EGFR and BRCAI might be candidate therapeutic targets in this disease. 


\section{Background}

Although the overall mortality due to breast cancer in the United States has decreased, attributed in part to breast screening and early application of various treatments, overall mortality in Japan is still increasing [1]. Breast cancers represent a heterogeneous group of tumors that are diverse in behavior, outcome, and sensitivity to therapy. To reduce mortality from breast cancer, it would be desirable to identify and characterize tumors having a poor prognosis. Emerging data demonstrate that stratification of tumors by gene expression profiles divides breast cancer into four common subtypes which are associated with different clinical outcome [2]. Two of them are estrogen receptor (ER)-positive (luminal and luminal/HER2+) and two are ER-negative (basal-like and HER2 positive) $[2,3]$.

Although the immunohistochemical staining profile can be a useful surrogate for gene expression analysis, the optimum immunohistochemical profile of the basal-like subtype remains unclear. However, the basal-like category is composed almost entirely of triple-negative breast cancers (TNBCs) (i.e., tumors lacking ER, progesterone receptor (PgR) and HER2 expression) [3-5]. A simplified method of classification, based on immunohistochemical assays for ER, PgR, and HER2, is clinically useful, and clinicians are increasingly taking triple-negative status into account in clinical decision-making and therapeutic protocol design. Epidermal growth factor receptor (EGFR) is more frequently expressed in TNBCs than in non-TNBCs $[6,7]$. Therefore, the EGFR is considered a candidate treatment target for TNBCs.

Cluster analyses of microarray expression profiling data have shown that familial BRCA1 mutant tumors tend to fall into the basal-like category [2]. Some studies have indicated that BRCA1 mRNA expression is lower in basallike sporadic cancers [8], and in approximately $30 \%$ of sporadic breast cancers [9]. It is believed that this may be the result of an epigenetic mechanism acting on the $B R C A 1$ gene or a dysfunction in the upstream pathways regulating BRCA1 expression $[8,10]$. These sporadic tumors with reduced $B R C A 1$ expression tend to be triplenegative, and remarkably similar to BRCA1-mutated tumors [8].

Here, we present data on a large series of TNBCs with long-term follow-up and data on the status of their EGFR and BRCA1 genes.

\section{Methods \\ Patients}

A total of 969 surgically resected breast carcinomas with tissue blocks available were selected from the archive of the Department of Breast and Endocrine Surgery, Nagoya City University Hospital in Japan. Specimens were obtained from patients who underwent surgery between January 1981 and December 2003. Tissues were fixed in $10 \%$ buffered formalin and embedded in paraffin or placed in liquid nitrogen immediately after resection and stored at $-80^{\circ} \mathrm{C}$ until DNA and RNA extraction. Informed consent was obtained before the surgery. The histological grade was estimated according to the Bloom and Richardson method proposed by Elston and Ellis [11]. Analysis of clinical outcome was performed in a total of 557 consecutive breast cancer patients operated from January 1981 to December 1999, because their clinicopathological and survival data were available for this study. Disease-free survival (DFS) was defined as the interval from the date of primary surgery to the first locoregional recurrence or distant metastasis. The distant disease-free survival (DDFS) was defined as the interval from the date of primary surgery to the identification of distant metastasis. The median follow-up period was 8.3 years (range 3 to 281 months). Relapse data were available in 543 of 557 patients examined: 159 (28.5\%) experienced disease recurrence; $99(17.7 \%)$ showed distant relapse; and 75 $(13.4 \%)$ had died. This protocol was approved by the Institutional Review Board of Nagoya City University Graduate School of Medical Sciences.

\section{DNA and RNA extraction}

Genomic DNA and total RNA from homogeneous microscopically confirmed breast cancer tissues was isolated from approximately $500 \mathrm{mg}$ of each frozen specimen using a phenol-chloroform extraction method for DNA extraction, and with TRIZOL reagent (Invitrogen Japan K.K., Tokyo, Japan) for RNA extraction according to the manufacturer's recommendations. Total RNA was also isolated from MCF-7 cells with TRIZOL reagent (Invitrogen).

\section{Immunohistochemical analysis}

One 4- $\mu \mathrm{m}$ section from each paraffin block specimen was first stained with hematoxylin and eosin in order to ascertain that an adequate number of invasive ductal carcinoma cells were present and that quality of fixation was adequate for immunohistochemical analysis. Serial sections $(4-\mu \mathrm{m})$ were then prepared from suitable blocks and float-mounted on adhesive-coated glass slides for ER $\alpha$, PgR, HER2, TP53, Ki67, cytokeratin (CK) 5/6, CK14 and EGFR staining. Primary antibodies were mouse monoclonal anti-human antibodies against ER $\alpha$ (1D5; DAKO, Glostrup, Denmark) at a 1:100 dilution, PgR (PgR636; DAKO) at a 1:100 dilution, TP53 (PAb1801; Novocastra, Newcastle, UK) at 1:50, Ki67 (MIB-1; DAKO) at 1:100, CK5/6 (D5/16 B4; DAKO) at 1:50 and CK14 (LL002; NeoMarkers, Fremont, CA) at 1:200. Rabbit anti-human cerbB2 oncoprotein antibody (DAKO) at a 1:200 dilution was used for HER2. The DAKO EnVision system (DAKO EnVision-labeled polymer, peroxidase) was used for 
detection of ER $\alpha$, PgR, HER2, Ki67, CK5/6, and CK14. The streptavidin-biotin system (SAB-PO kit; Nichirei Co., Inc., Tokyo, Japan) was applied for detection of the bound TP53 antibody. Immunostaining for EGFR was performed using the EGFRpharmDx assay detection system (prediluted; DAKO).

\section{Interpretation of immunohistochemical staining}

Immunostained specimens were scored after the entire slide had been evaluated by light microscopy. The expression of ER $\alpha$ was scored by assigning a proportion score and an intensity score according to Allred's procedure [12]. Any brown nuclear staining in invasive breast epithelium was counted toward the proportion score. Tumors with scores of 3 or greater were considered to be positive for ER $\alpha$ expression. HER2 immunostaining was evaluated using the same method as is employed by the HercepTest (DAKO). To determine the score of HER2 expression the membrane staining pattern was estimated and scored on a scale of 0 to $3+$. Tumors with scores of 0 and 1 were considered to be negative, and tumors with a score of 3 were considered to be positive for HER2 overexpression. All tumors with a score of 2 were omitted from the analysis in this study because fluorescent in situ hybridization (FISH) analysis was not carried out on them. In the case of TP53, tumors were considered immunohistochemically positive when $\geq 10 \%$ of the tumor cells showed nuclear staining $[13,14]$. The expression status of Ki67 was assessed according to the estimated proportion of nuclear staining of tumor cells that were positively stained. Scoring criteria for Ki67 were as follows (in the form proportion of nuclear staining $=$ score): none $=0$, $<1 / 100=1,1 / 100-1 / 10=2,1 / 10-1 / 2=3$, and $>1 / 2=4$ [15]. Tumors with a score of $\underline{3}$ or greater for Ki67 were considered to have high Ki67 expression. Positivity for CK5/6 and CK14 was defined as the detection of more than $5 \%$ of invasive tumor cells showing strong cytoplasmic and membrane staining [16]. Immunostaining for EGFR was interpreted as positive when at least $10 \%$ of tumor cells showed strong membrane staining $[7,17]$.

\section{Genetic analysis of EGFR}

The primers and TaqMan probes were designed for 14 known mutations in the EGFR gene [18]. TaqMan genotyping assays for EGFR mutations were performed on Applied Biosystems 7500 Fast Real-Time PCR equipment (Applied Biosystems) as described previously [18]. The results were analyzed using the allelic discrimination assay program [18].

\section{Real-Time Reverse Transcription (RT)-PCR}

RT was performed as described previously [22]. Real-time quantitative RT-PCR of the BRCA1 gene was performed using TaqMan Universal PCR Master Mix (Applied Biosystems) in the Applied Biosystems 7500 Fast Real-Time PCR
System, following the manufacturer's instructions. The primers and probes for the BRCA1 mRNA expression assay are commercially available (TaqMan Gene Expression Assays, Assay ID: Hs00173233_m1, Applied Biosystems). The PCR conditions were as follows: initial denaturation at $95^{\circ} \mathrm{C}$ for $2 \mathrm{sec}$, followed by 40 cycles of $95^{\circ} \mathrm{C}$ for $3 \mathrm{sec}$, and $60^{\circ} \mathrm{C}$ for $30 \mathrm{sec}$. To ensure the fidelity of mRNA extraction and reverse transcription, BRCA1 signals from all samples were normalized against GAPDH as an internal control. The primers and probes for GAPDH mRNA expression assay are commercially available (TaqMan Gene Expression Assays, Assay ID: Hs99999905_m1, Applied Biosystems). The PCR conditions for amplification of GAPDH were as follows: initial denaturation at $95^{\circ} \mathrm{C}$ for $2 \mathrm{sec}$, followed by 40 cycles of $95^{\circ} \mathrm{C}$ for $3 \mathrm{sec}$, and $60^{\circ} \mathrm{C}$ for $30 \mathrm{sec}$. For each PCR run, a standard curve was constructed with serial dilutions of cDNA obtained from MCF-7 cells, which express BRCA1 mRNA.

\section{Statistical analyses}

All molecular and immunohistochemical analyses were performed blinded to clinical data. Statistical calculations were performed with StatView-J 5.0 software (SAS Institute Inc., Cary, NC). The relationship between the frequency of TNBC or non-TNBC and clinicopathologic factors were assessed by $\chi^{2}$ and Fisher's exact probability tests. The Mann-Whitney U-test was performed for the analyses of the EGFR gene copy number and BRCA1 mRNA expression. DFS and DDFS curves were generated by the Kaplan-Meier method and verified by the log-rank test. Cox proportional hazards regression analysis was used for univariate and multivariate analyses of prognostic values. Differences were considered significant when a $P$ value $<0.05$ was obtained.

\section{Results}

Patient Characteristics and Immunohistochemical results

In total, 969 Japanese cases of invasive breast cancer undergoing surgery at Nagoya City University Hospital from January 1981 to December 2003 were informative for the 3 markers ER, PgR, and HER2. Of these informative cases, $110(11.3 \%)$ were found to be TNBCs. Immunohistological analyses of TP53 and Ki67, and clinicopathological analysis were performed in 531 consecutive patients from 1981 to 1999 . Table 1 shows the features of 71 TNBCs compared with 415 non-TNBCs concerning different clinicopathological variables and biomarkers. All tumors with a HER2 score 2+ were omitted from this analysis, as indicated in Methods. TNBC was significantly associated with grade 3 tumors $(\mathrm{P}<0.0001)$, with TP53 protein accumulation $(\mathrm{P}<0.0001)$ and with high $\mathrm{Ki67}$ expression $(\mathrm{P}<0.0001)$, as well as lymph node status $(\mathrm{P}$ $=0.02)$. 
Table I: Characteristics of Patients with Different Tumor Subtypes

\begin{tabular}{|c|c|c|c|c|c|c|c|}
\hline \multirow[t]{3}{*}{ Variables } & \multirow{2}{*}{\multicolumn{2}{|c|}{$\begin{array}{c}\text { Total } \\
N=486(100 \%)\end{array}$}} & \multirow{2}{*}{\multicolumn{2}{|c|}{$\begin{array}{c}\text { Triple negative } \\
\qquad N=7 /(I 5 \%)\end{array}$}} & \multirow{2}{*}{\multicolumn{2}{|c|}{$\begin{array}{c}\text { Non-triple negative } \\
\text { N }=415 \text { (85\%) }\end{array}$}} & \multirow[t]{3}{*}{$P$ value } \\
\hline & & & & & & & \\
\hline & No. & $\%$ & No. & $\%$ & No. & $\%$ & \\
\hline Age, years & & & & & & & 0.49 \\
\hline$\leq 50$ & 198 & 41 & 32 & 44 & 166 & 40 & \\
\hline$>50$ & 288 & 59 & 39 & 56 & 249 & 60 & \\
\hline Size & & & & & & & 0.23 \\
\hline$\leq 2 \mathrm{~cm}$ & 181 & 37 & 21 & 30 & 160 & 39 & \\
\hline$>2 \mathrm{~cm}$ & 288 & 59 & 46 & 65 & 242 & 58 & \\
\hline Unknown & 17 & & 4 & 5 & 13 & 3 & \\
\hline Nodal status & & & & & & & 0.02 \\
\hline Negative & 275 & 57 & 48 & 68 & 227 & 55 & \\
\hline Positive & 192 & 40 & 19 & 27 & 173 & 42 & \\
\hline Unknown & 19 & 3 & 4 & 5 & 15 & 3 & \\
\hline Histology & & & & & & & 0.14 \\
\hline Ductal & 454 & 94 & 66 & 93 & 388 & 93 & \\
\hline Lobular & 16 & 3 & 0 & 0 & 16 & 4 & \\
\hline Other & 16 & 3 & 5 & 7 & 11 & 3 & \\
\hline Grade & & & & & & & $<0.0001$ \\
\hline 1 & 92 & 19 & 4 & 6 & 88 & 21 & \\
\hline 2 & 273 & 56 & 32 & 45 & 241 & 58 & \\
\hline 3 & 101 & 21 & 34 & 48 & 67 & 16 & \\
\hline Unknown & 20 & 4 & 1 & I & 19 & 5 & \\
\hline TP53 expression & & & & & & & $<0.0001$ \\
\hline Negative & 392 & 81 & 43 & 61 & 349 & 84 & \\
\hline Positive & 92 & 19 & 28 & 39 & 64 & 15 & \\
\hline Unknown & 2 & 0 & 0 & 0 & 2 & 1 & \\
\hline Ki67 expression & & & & & & & $<0.0001$ \\
\hline Low & 333 & 69 & 34 & 48 & 299 & 72 & \\
\hline High & 150 & 31 & 37 & 52 & 113 & 27 & \\
\hline Unknown & 3 & I & 0 & 0 & 3 & 1 & \\
\hline
\end{tabular}

Next, immunohistological analyses of EGFR, CK 5/6, and CK14 were performed for all TNBCs available in this study, operated from January 1981 to December 2003. As shown in Table 2, 31\% (33 cases) of TNBC were positive for EGFR protein, $52 \%$ (57 cases) expressed CK5/6, and $55 \%$ (61 cases) CK14. A total of $77(70 \%)$ had a basal-like phenotype according to Nielsen's definition (TNBC with CK5/6 and/or EGFR expression) [3,4].

\section{Genomic analysis of EGFR}

We sought mutations in the EGFR gene in TNBCs, because EGFR mutations were found in a subset of Japanese nonsmall lung cancers, despite being very rare in Caucasians [23], and because these mutations were suggested to predict responses to gefitinib therapy $[23,24]$. The sequences of primers and probes in TaqMan genotyping assays for the EGFR gene are shown in Table 3. Genomic DNA was available in 63 of 110 TNBC tissues, and genotyping could be successfully performed for the 14 known EGFR mutations in 58 of these. However, none of the 58 TNBC showed any known EGFR mutations. We previously reported an increased EGFR copy number in a subset of Japanese non-small lung cancers [18]. As 31\% of TNBCs were positive for EGFR protein in this series, we measured EGFR gene copy number in 63 TNBCs compared with 42 ER and/or PgR-positive but HER2-negative consecutive breast cancers, (which are also termed luminal subtype [2]). It was found that $21 \%$ (12 cases) of TNBCs contained an increased EGFR gene copy number while only one (2\%) of luminal subtype tumors showed slightly increased EGFR gene copy (Mann-Whitney U-test: $P=$ 0.016 , Fig. 1). We then sought any correlations between the EGFR gene copy number and EGFR protein expression based on the immunohistochemical analysis in TNBCs. Only 2 of 14 TNBCs showing EGFR protein expression demonstrated increased EGFR gene copy number (Table 4). There were no significant correlations between these parameters.

EGFR gene copy numbers in breast cancer tissues were estimated with 7500 Fast Real-Time PCR using a QuantiTect SYBR Green Kit (Qiagen Inc, Valencia, CA) as described previously [18]. Briefly, we have quantified each tumor DNA by comparing the target locus to the reference Line-1, a repetitive element for which copy numbers per haploid genome are similar among all normal and neo- 
Table 2: Immunohistochemical Findings in Triple Negative Breast Cancer

\begin{tabular}{lcc}
\hline \multicolumn{1}{c}{ Variables } & \multicolumn{2}{c}{ Triple negative (N = I l0) } \\
\cline { 2 - 3 } & No. & $\%$ \\
\hline EGFR & & \\
Negative & 69 & 62 \\
Positive & 33 & 31 \\
Unknown & 8 & 7 \\
Cytokeratin 5/6 & & \\
Negative & 47 & 43 \\
Positive & 57 & 52 \\
Unknown & 6 & 5 \\
Cytokeratin 14 & & \\
Negative & 43 & 40 \\
Positive & 61 & 55 \\
$\quad$ Unknown & 6 & 5 \\
Cytokeratin 5/6/I4 & & \\
Negative & 32 & 30 \\
Posotive & 72 & 65 \\
Unknown & 6 & 5 \\
Basal-like phenotype & & \\
Negative & 24 & 70 \\
Positive & 77 & 8 \\
Unknown & 9 & \\
\hline
\end{tabular}

plastic human cells $[19,20]$. The relative EGFR copy number level was normalized to normal human genomic DNA as the calibrator. Copy number changes relative to the Line-1 gene and the calibrator were determined by the formula $\left(\mathrm{T}_{\text {EGFR }} / \mathrm{T}_{\text {Line-1 }}\right) /\left(\mathrm{C}_{\text {EGFR }} / \mathrm{C}_{\text {Line-1 }}\right)$, where $\mathrm{T}_{\text {EGFR }} / \mathrm{T}_{\text {Line-1 }}$ are quantity from tumor DNA by using EGFR and Line-1, and $\mathrm{C}_{\mathrm{EGFR}} / \mathrm{C}_{\text {Line-1 }}$ are quantity from calibrator by using EGFR and Line-1 $[19,20]$. Primer sequences for the EGFR gene used in this study were: forward, CCACCAAATTAGCCTGGACA; reverse, CGCGACCCTTAGGTATTCTG. EGFR gene copy number $>3$ was defined as positive [21].

\section{BRCAI mRNA expression analysis}

Loss of BRCA1 function has been found in basal-like breast cancer. Therefore, we assessed BRCA1 mRNA expression in 61 TNBC and 60 consecutive luminal subtype breast cancers. As shown in Fig. 2, BRCA1 mRNA expression was significantly decreased in TNBCs compared to luminal subtype breast cancers. BRCA1 gene mutations were not analyzed in this study. Therefore, TNBCs in our series may include both BRCA1-mutant and sporadic TNBCs. Nonetheless, the fact remains that significantly reduced $B R C A 1 \mathrm{mRNA}$ expression was observed in these Japanese TNBCs.

\section{Clinical outcome by treatment epoch}

Although adjuvant therapies are effective in breast cancers, their employment was not yet standard practice in Japan in the 1980's. Here, we first compared the outcome for breast cancer patients treated at Nagoya City Univer- sity Hospital in the 1980's with those treated in the 1990 's. All patients treated later tended to show better DDFS compared with those treated in the 1980's (Fig. 3a). Patients with tumors of luminal subtype treated in the 1990 's showed significantly better DDFS than those from the 1980's ( $P=0.02$, Fig. 3b). In contrast, DDFS of patients with TNBC treated either in the 1980's or 1990's was similar (Fig. 3c). Only 58\% (61/106 cases) of patients with luminal subtype tumors treated in the 1980's received adjuvant tamoxifen therapy while this figure increased to $78 \%$ (194/248 cases) in the 1990's. Therefore, a higher rate of adjuvant hormone therapy might be associated with better DDFS in patients with luminal subtype tumors. For TNBCs, 31\% (12/39 cases) treated in the 1980 's received chemotherapy (10 patients received oral 5-fluorouracil (5-FU), and 2 were treated with an anthracycline-based regimen) while 38\% (12/32 cases) received chemotherapy in the 1990's (11 oral 5-FU, and one CMF (cyclophosphamide/methotrexate/5-FU)-based regimen). Because both the percentage of patients on adjuvant therapy and the adjuvant chemotherapy regimens themselves were similar for TNBC patients in the 1980's and the 1990's, the outcomes in these two treatment epochs were considered to be similar.

\section{Clinical outcome according to tumor subtype}

Next, we analyzed the outcome of all patients treated from 1981 to 1999 ( $\mathrm{n}=531)$ to compare TNBCs with nonTNBCs. We found that TNBC was not associated with poor DDFS overall (Fig. 4a). Non-TNBC were classified into 3 subtypes as follows: 1) luminal subtype (ER+ and/ or PgR+ and HER2-), 2) luminal/HER2+ subtype (ER+ and/or PgR+ and HER2+), and 3) HER2+ subtype (ERand PgR- and HER2+) [3]. Within 5 years of diagnosis, the Kaplan-Meier survival curves of TNBC and HER2+ subtype patients were similar (Fig. 4b). Thereafter, however, the survival curve of TNBCs more closely approximated luminal subtype. DDFS was significantly different between luminal and luminal/HER2+ subtypes ( $\mathrm{P}=$ 0.0008 ) but not between TNBC and any other subtype (Fig. 4b). For luminal/HER2+ subtype patients, 6 (27\%) received no adjuvant therapy and 7 (32\%) received adjuvant tamoxifen alone. Therefore, patients with luminal/ HER2 + subtype tumor could be considered to have been under-treated in this series.

In our series, $68 \%$ of TNBCs were node-negative but only $53 \%$ of non-TNBCs ( $P=0.02$, Table 1$)$. Therefore, we next analyzed the clinical outcome only in node-negative breast cancers. Fifteen patients (31\%) having node-negative TNBC received adjuvant chemotherapy (13 oral 5-FU, and 2 anthracycline-based regimen) while 26 (54\%) received no adjuvant therapy. Medical records of 7 patients (15\%) having node-negative TNBC were missing. The results show that node-negative TNBC was associated 
Table 3: Sequence of the mutation-specific TaqMan probes and PCR primers for the EGFR gene

\begin{tabular}{|c|c|c|c|c|}
\hline Mutation No. & Probe name & Nucleotide & Amino Acid & $\begin{array}{l}\text { Primer sequence } \\
\text { (forward) }\end{array}$ \\
\hline & WTI & & & $\begin{array}{c}\text { CCCAGAAGGTGAGAAAG } \\
\text { TTAAAATTC }\end{array}$ \\
\hline I & Del la & 2235-2249del & E746-A750del & (same as above) \\
\hline 2 & Del Ib & 2236-2250del & & (same as above) \\
\hline \multirow[t]{2}{*}{3} & Del 2 & $2254-2277 \mathrm{del}$ & S752-1759del & (same as above) \\
\hline & WT2 & & & (same as above) \\
\hline 4 & Del 3 & 2239-2247del, 2248G>C & L747-E749del, A750P & (same as above) \\
\hline 5 & Del 4 & $2240-2257 \mathrm{del}$ & L747-S752del, P753S & (same as above) \\
\hline 6 & Del 5 & $2238-2255 \mathrm{del}, 2237 \mathrm{~A}>\mathrm{T}$ & L747-A750del, E746V & (same as above) \\
\hline \multirow[t]{2}{*}{7} & Del 6 & $2240-225$ I del & L747-A750del, T747S & (same as above) \\
\hline & WT3 & & & $\begin{array}{c}\text { TGAGGATCTTGAAGGAAA } \\
\text { CTGAATTC }\end{array}$ \\
\hline 8 & G7I9C & $2155 \mathrm{G}>\mathrm{T}$ & G719C & (same as above) \\
\hline \multirow[t]{2}{*}{9} & G7I9S & $2155 G>A$ & G7I9S & (same as above) \\
\hline & WT4 & & & $\begin{array}{c}\text { CCGCAGCATGTCAAGAT } \\
\text { CAC }\end{array}$ \\
\hline \multirow[t]{2}{*}{10} & L858R & $2573 \mathrm{~T}>\mathrm{G}$ & L858R & (same as above) \\
\hline & WT5 & & & (same as above) \\
\hline \multirow[t]{2}{*}{11} & L86IQ & $2582 T>A$ & L86IQ & (same as above) \\
\hline & WT6 & & & $\begin{array}{c}\text { CCCAGAAGGTGAGAAAG } \\
\text { TTAAAATTC }\end{array}$ \\
\hline 12 & L747Del & 2239-2262del & L747-K754del & (same as above) \\
\hline \multirow[t]{2}{*}{13} & N756Ins & 2265-2267InsCAA & N756Ins & (same as above) \\
\hline & WT7 & & & $\begin{array}{c}\text { GGAGGACCGTCGCTTGG } \\
\mathrm{T}\end{array}$ \\
\hline 14 & L838P & $2513 T>C$ & L838P & (same as above) \\
\hline
\end{tabular}

\begin{tabular}{|c|c|}
\hline TaqMan probe & $\begin{array}{l}\text { Primer sequence } \\
\text { (reverse) }\end{array}$ \\
\hline $\begin{array}{l}\text { VIC- } \\
\text { ATTAAGAGAAGCAACATC } \\
T\end{array}$ & $\begin{array}{l}\text { CCCACACAGCAAAGCAG } \\
\text { AAA }\end{array}$ \\
\hline $\begin{array}{l}\text { FAM- } \\
\text { CGCTATCAAAACATCT }\end{array}$ & (same as above) \\
\hline $\begin{array}{l}\text { FAM- } \\
\text { CTATCAAGACATCTCC }\end{array}$ & (same as above) \\
\hline $\begin{array}{l}\text { FAM- } \\
\text { AGAAGCAACACTCGAT }\end{array}$ & (same as above) \\
\hline VIC-CGAAAGCCAACAAG & (same as above) \\
\hline $\begin{array}{l}\text { FAM- } \\
\text { CAAGGAACCAACATC }\end{array}$ & (same as above) \\
\hline $\begin{array}{l}\text { FAM- } \\
\text { AAGGAATCGAAAGCC }\end{array}$ & (same as above) \\
\hline $\begin{array}{l}\text { FAM- } \\
\text { CAAGGTTCCGAAAGC }\end{array}$ & (same as above) \\
\hline $\begin{array}{l}\text { FAM- } \\
\text { TCAAGGAATCATCTCC }\end{array}$ & (same as above) \\
\hline VIC-AAGTGCTGGGCTCC & $\begin{array}{l}\text { TGCCAGGGACCTTACCT } \\
\text { TATACA }\end{array}$ \\
\hline $\begin{array}{l}\text { FAM- } \\
\text { AAAGTGCTGTGCTCC }\end{array}$ & (same as above) \\
\hline $\begin{array}{l}\text { FAM- } \\
\text { AAAGTGCTGTGCTCC }\end{array}$ & (same as above) \\
\hline VIC-TTGGGCTGGCCAAA & $\begin{array}{l}\text { TCCTTCTGCATGGTATTC } \\
\text { TTTCTCT }\end{array}$ \\
\hline FAM-TTGGGCGGGCCAA & (same as above) \\
\hline VIC-CCAAACTGCTGGGTG & (same as above) \\
\hline $\begin{array}{l}\text { FAM- } \\
\text { CCAAACAGCTGGGTG }\end{array}$ & (same as above) \\
\hline
\end{tabular}


Table 3: Sequence of the mutation-specific TaqMan probes and PCR primers for the EGFR gene (Continued)

\begin{tabular}{ll}
\hline VIC- & CCCACACAGCAAAGCAG \\
ATTAAGAGAAGCAACATC & AAA \\
T & \\
FAM- & (same as above) \\
CTATCAAGGAAGCCAACA & \\
A-MGB & \\
FAM- & (same as above) \\
CCAACAACAAGGAAAT- & \\
MGB & \\
VIC-CGCGACCTGGCAG- & CCCAAAATCTGTGATCTT \\
MGB & GACATG \\
FAM-CGCGACCCGGCAG- & (same as above) \\
MGB &
\end{tabular}

with shorter DDFS than node-negative non-TNBC (Fig. 4c). When DDFS of node-negative TNBCs was compared with other subtypes, a significant difference was observed only between TNBC and luminal subtype (Fig. 4d). As shown in Fig. 4e, grade 1 node-negative TNBCs demonstrated no distant metastasis. However, the number of these patients was very small. Univariate Cox regression analysis indicated that only nodal status was associated with DDFS in TNBCs (Table 5).

\section{Discussion}

Although adjuvant hormone therapy was shown to be effective for ER-positive breast cancers [25], and adjuvant trastuzumab therapy was also shown to improve the survival of HER2 positive breast cancers [26,27], TNBCs have no targeted therapy at present. We screened TNBCs for 14 known EGFR mutations previously reported in lung cancers [18] but failed to find any. Gefitinib was reported to be effective not only in lung cancers with EGFR mutations $[23,24,28]$, but also for lung or colorectal cancers expressing EGFR protein or with increased EGFR gene copy number $[20,29]$. In our study, $31 \%$ of TNBCs were found to express EGFR protein, so could be candidates for gefitinib therapy. We also analyzed EGFR gene copy numbers of TNBCs by the PCR method [19-21], and found frequent increases in TNBCs compared with luminal subtype breast cancers. Although lung cancers having EGFR mutations were reported to be responsive to gefitinib therapy, about $10 \%$ of lung cancers without EGFR mutations were also susceptible to this therapy [28]. Therefore, even though no EGFR mutations were found in TNBCs in this study, TNBCs with increased EGFR gene copy number might still be candidates for therapy with anti-EGFR monoclonal antibodies such as gefitinib. We performed FISH assays on representative tumors with increased EGFR copy number [30] but could not compare the PCR and FISH assays. The reason for this was most likely the condition of the paraffin-embedded tissues not being good enough, because we did not see either EGFR or CEP7 signals as a control (data not shown). In our study, EGFR protein expression was not consistently accompanied by increased EGFR gene copy number. One of the reasons for lack of correlation between EGFR gene copy number and immunohistochemistry could be the technique used in this study. EGFR protein expression is generally heterogeneous. If a frozen tissue with PCR technique is used, it is subjected to the "dilution effect" and could be responsible for non-correlation in at least some cases. In lung cancers, increased EGFR gene copy number was also reported not to be consistently accompanied by positivity for EGFR protein, as assessed by immunohistochemistry [32]. Although we did not obtain FISH data for TNBCs with increased EGFR gene copy numbers, we are confident that the EGFR gene copy number data are reliable because the methodology to measure this gene is well-established [19$21]$, and in this series a significant difference in EGFR gene copy number was observed between TNBCs and luminal subtype tumors.

Basal-like breast cancer was reported to frequently possess BRCA1 germline mutations [2], and BRCA1 mRNA expression was also shown to be lower in sporadic basal-

Table 4: Relationship between EGFR Copy Number and the Immunohistochemical staining of EGFR protein in Triple Negative Breast Cancer

Increased EGFR gene copy No. No increased EGFR gene copy No.

EGFR IHC

0

I

2

3
6

2
14
22
8
2

IHC, immnohistochemistry 


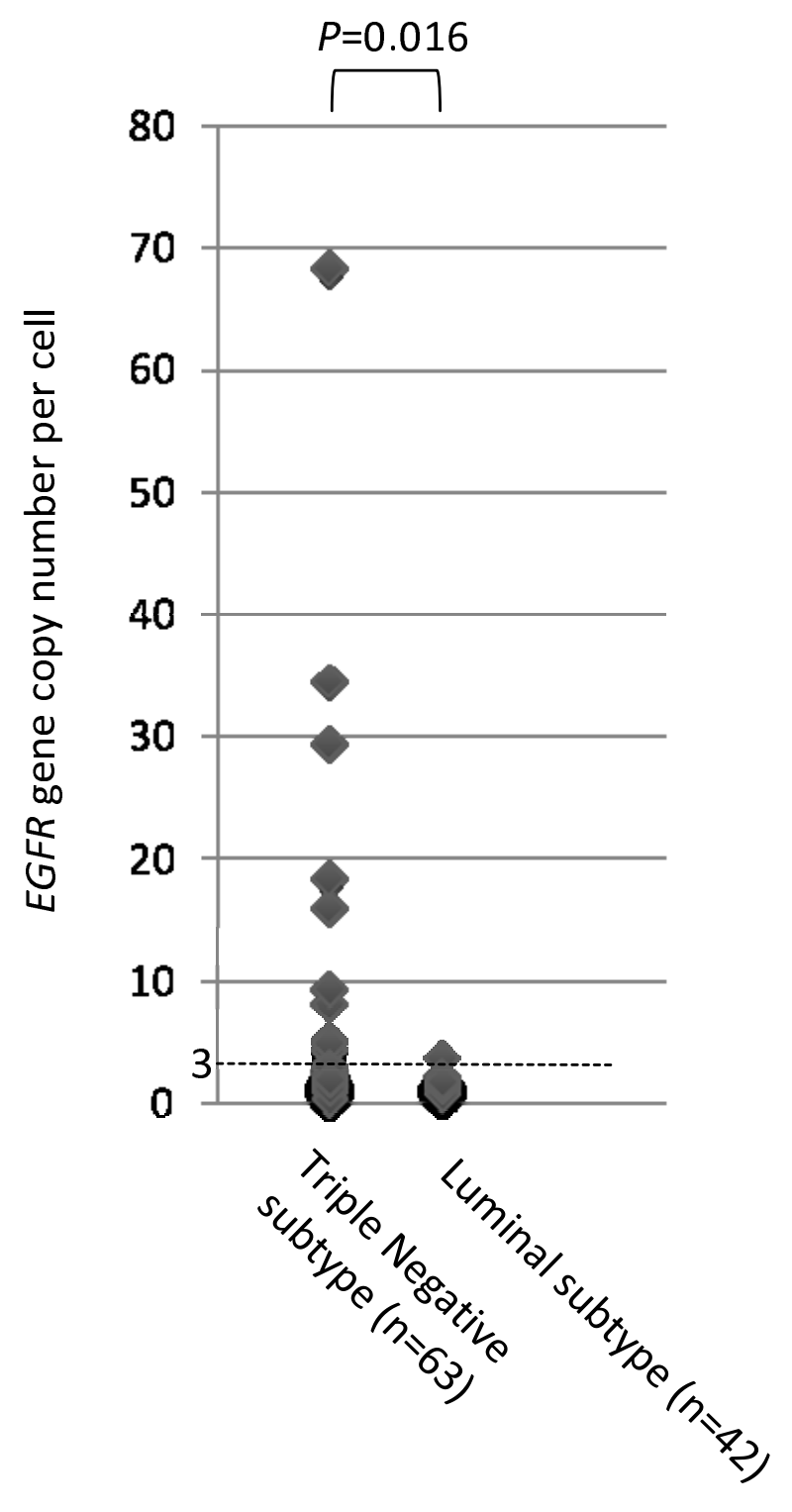

Figure I

Epidermal growth factor receptor (EGFR) gene copy number in triple-negative and luminal subtypes in Japanese breast cancer patients.

like breast cancers [8]. The profound similarities between hereditary BRCA1-related breast cancers and basal-like breast cancers suggest a fundamental defect in the BRCA1 pathway in sporadic basal-like breast cancers $[33,34]$. Recently, BRCA1 has been demonstrated to play a critical role in the differentiation of ER-negative stem/progenitor cells to ER-positive luminal cells, and it was reported that loss of BRCA1 function resulted in the accumulation of

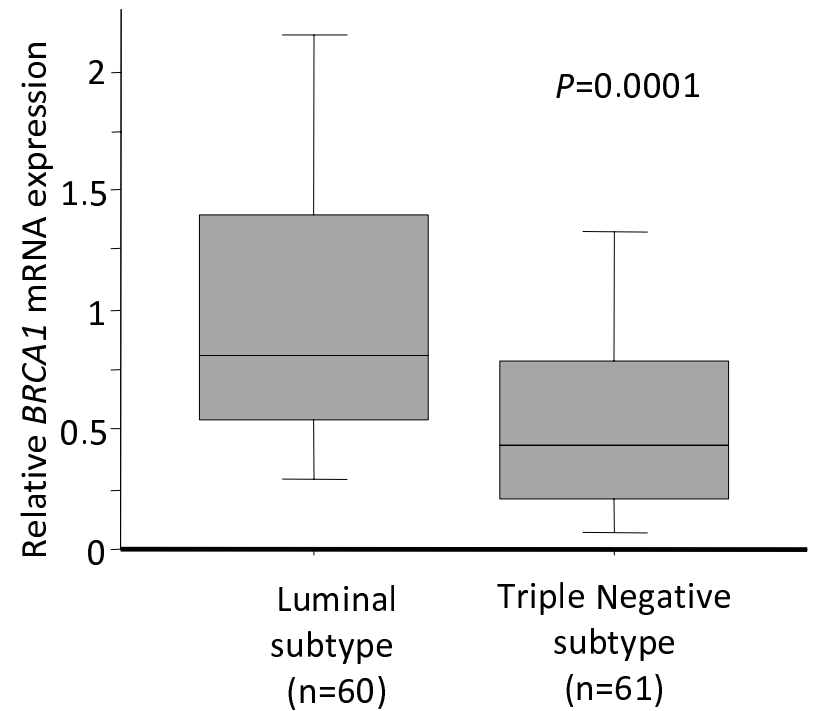

\section{Figure 2}

$B R C A$ ImRNAexpression in triple-negative and luminal subtypes in Japanese breast cancer patients.

ER-negative stem/progenitor cells, candidates for a cancer stem cell in the basal-like subtype [35]. BRCA1 was demonstrated to have an important role for DNA doublestrand break repair by homologous recombination [36].
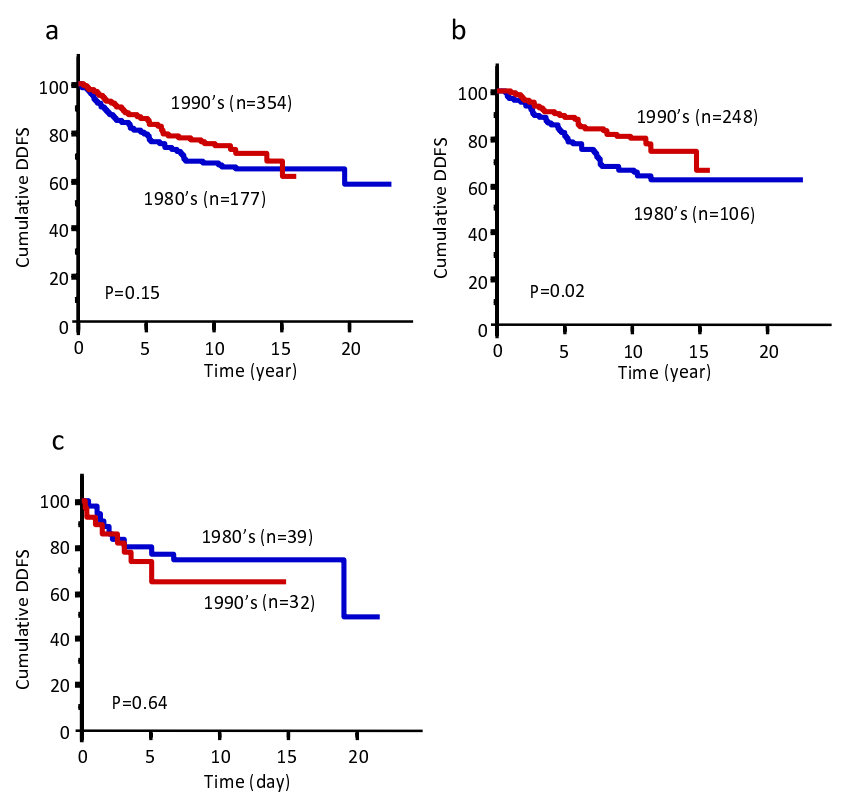

Figure 3

Distant disease-free survival (DDFS) according to the treatment epoch. (a) all patients, (b) luminal subtype breast cancer patients alone, (c) triple-negative breast cancer patients alone. 
a
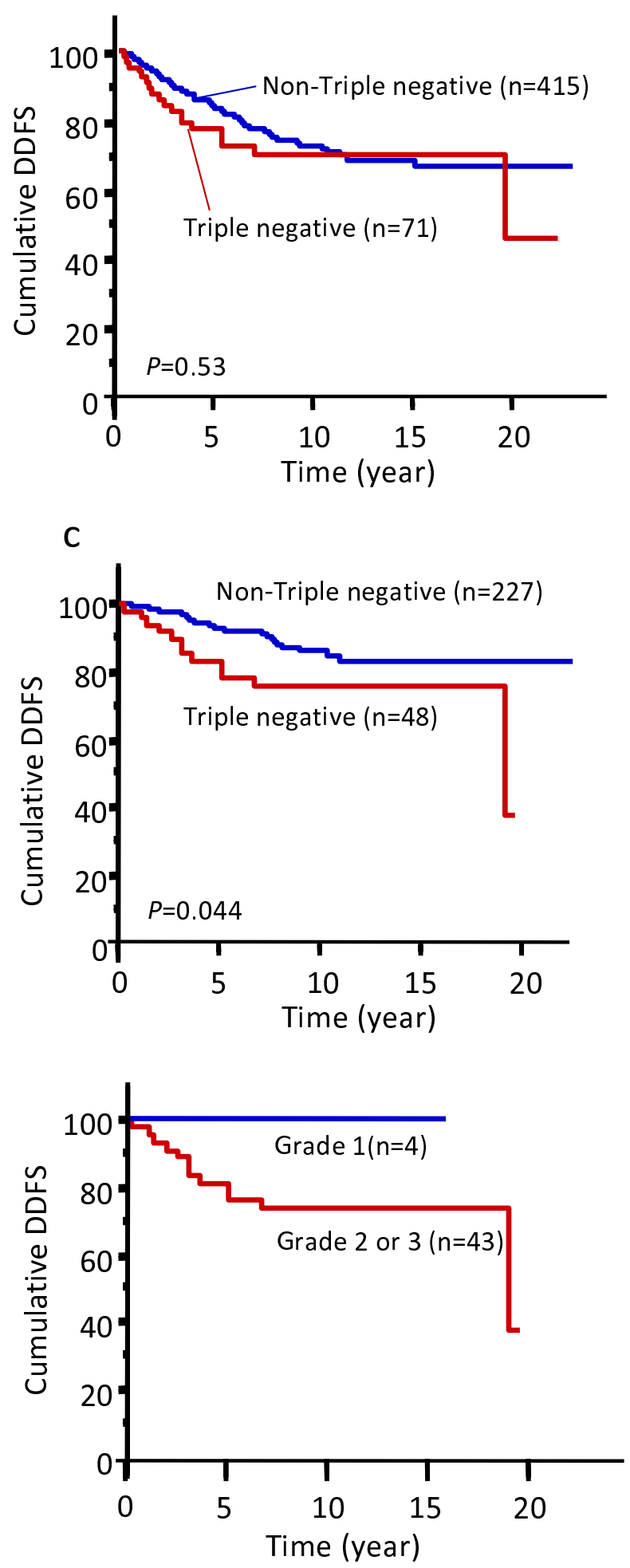

b
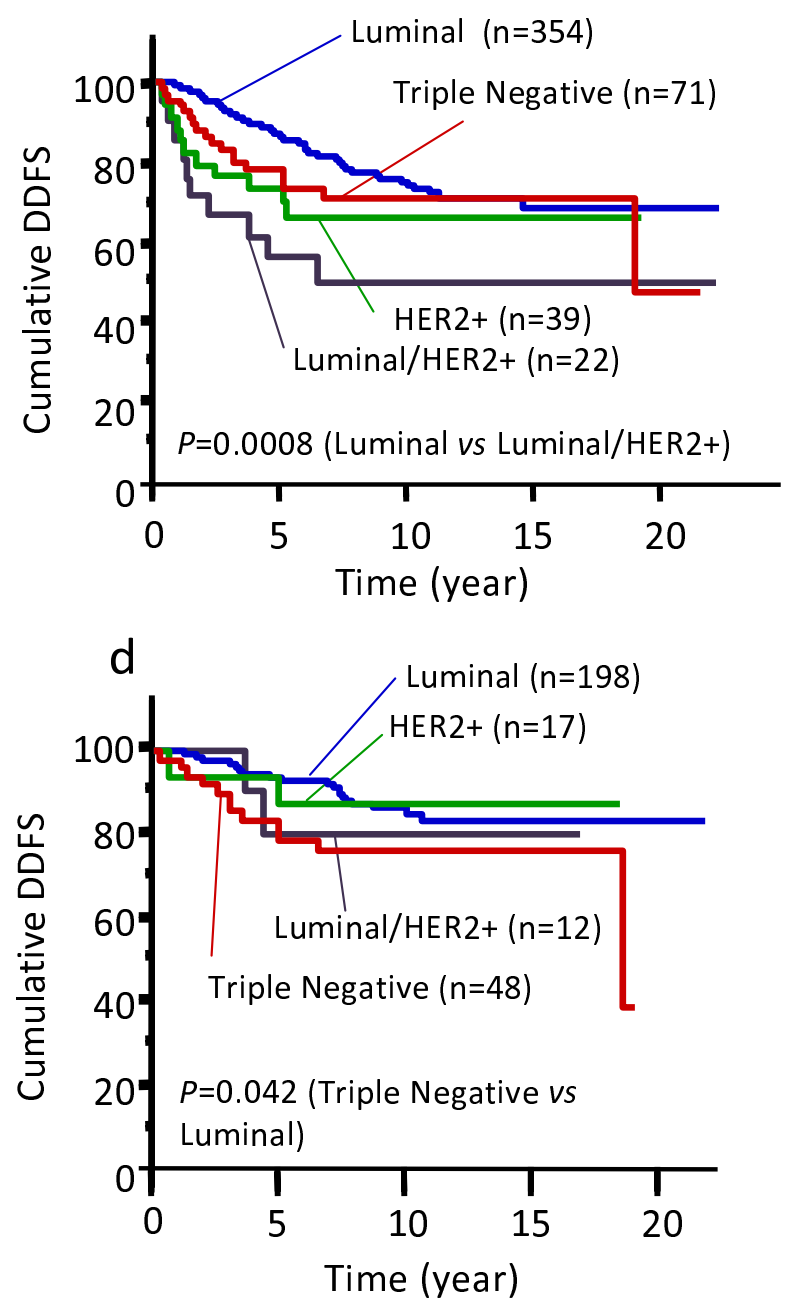

Figure 4

Distant disease-free survival (DDFS) according to breast cancer subtype. (a)(b) all patients, (c)(d) node-negative patients alone, (e) node-negative triple-negative breast cancer patients alone. 
Table 5: Univariate Cox Regression Analysis of Factors Associated with Distant Disease-free Survival in the Triple-Negative Tumors

\begin{tabular}{|c|c|c|}
\hline Variables & $P$ value & Relative Risk of recurrence $(95 \% \mathrm{Cl})$ \\
\hline \multicolumn{3}{|l|}{ Size } \\
\hline$\leq 2 \mathrm{~cm}$ & & I.0 (reference) \\
\hline$>2 \mathrm{~cm}$ & 0.92 & $1.26(0.44$ to 3.65$)$ \\
\hline \multicolumn{3}{|l|}{ Nodal status } \\
\hline Negative & & I.0 (reference) \\
\hline Positive & 0.02 & $2.60(1.14$ to 6.96$)$ \\
\hline \multicolumn{3}{|l|}{ Grade } \\
\hline 1 & & I.0 (reference) \\
\hline 2,3 & 0.22 & 2.46 (0.68 to 10.39$)$ \\
\hline \multicolumn{3}{|l|}{ TP53 expression } \\
\hline Negative & & I.0 (reference) \\
\hline Positive & 0.61 & $\mathrm{I} .12(0.72$ to 1.77$)$ \\
\hline \multicolumn{3}{|l|}{ Ki67 expression } \\
\hline Low & & I.0 (reference) \\
\hline High & 0.55 & 0.88 (I.59 to 1.34$)$ \\
\hline \multicolumn{3}{|l|}{ EGFR IHC } \\
\hline Negative & & I.0 (reference) \\
\hline Positive & 0.88 & $1.07(0.48$ to 2.36$)$ \\
\hline \multicolumn{3}{|l|}{ EGFR gene copy number } \\
\hline$<3$ & & I.0 (reference) \\
\hline$\geq 3$ & 0.2 & $0.27(0.03$ to 2.05$)$ \\
\hline \multicolumn{3}{|l|}{ Cytokeratins } \\
\hline Negative & & I.0 (reference) \\
\hline Positive & 0.42 & $0.72(0.33$ to 1.68$)$ \\
\hline \multicolumn{3}{|l|}{ Basal like type } \\
\hline+ & & I.0 (reference) \\
\hline- & 0.67 & $0.79(0.34$ to 1.80$)$ \\
\hline
\end{tabular}

IHC, immunohistochemistry

Poly(ADP-ribose) polymerase (PARP) is an enzyme involved in base excision repair, a key pathway in the repair of DNA single-strand breaks [37]. Recently, BRCA1/ 2 dysfunction has been shown to sensitize cells to the inhibition of PARP enzymatic activity [38]. Therefore, PARP inhibitors may be key drugs for treating TNBCs [38].

Although patients with TNBCs were reported to have a poor prognosis $[6,39]$, the recurrent pattern of TNBCs was different from non-TNBCs [40-42]. Dent et al [40] reported that TNBC patients had an increased likelihood of recurrence and death within 5 years of diagnosis but not thereafter, while the recurrent risk among non-TNBCs was shown to be stable over the period of follow-up. Liedtke et al [41] described the clinical course of 1,118 breast cancer patients who received neoadjuvant chemotherapy. Twenty-three percent of these women had TNBC, and showed an increased likelihood of 3-year progression-free survival and 3-year overall survival [41]. The clinical course of TNBCs in our series was very similar to these previous reports [40-42].

Patients with TNBC were reported to have increased pathological complete response rates (pCR) to neoadjuvant chemotherapy compared with non-TNBC $[41,43,44]$. However, TNBC patients with residual disease after neoadjuvant chemotherapy had worse survival compared with non-TNBC patients [41,43]. Carey et al [43] termed this characteristic of TNBCs "the triple negative paradox". The higher sensitivity to neoadjuvant chemotherapy in TNBCs may suggest that patients with TNBC should be treated more intensively including with novel therapeutic alternatives. In this series, node-negative TNBCs showed poorer prognosis than node-negative non-TNBCs. Nodenegative TNBCs could thus be considered to have been under-treated with adjuvant therapy in this series. On the other hand, no recurrence occurred in grade 1 node-negative TNBCs, although this subgroup was very small. This might indicate another issue as to how to classify TNBCs into subgroups that would benefit from more intensive adjuvant therapy. In this study, we did not find any useful prognostic markers of TNBCs although they showed higher positivity for TP53 protein accumulation and higher Ki67 expression.

\section{Conclusion}

Frequently increased EGFR copy number and EGFR protein expression, and decreased BRCA1 mRNA expression, 
were observed in Japanese triple-negative breast cancers. EGFR and BRCA1 might be candidates for targeted therapies.

\section{Competing interests}

The authors declare that they have no competing interests.

\section{Authors' contributions}

TT conceived and designed the study and drafted the manuscript. NK carried out mRNA expression assay. TT, HY and ST carried out immunohistochemical analysis. KO and HS carried out mutation and amplification assays. HI and YF were involved in data acquisition and interpretation. All authors read and approved the final manuscript.

\section{Acknowledgements}

This work was supported by a Grant-in-Aid for Scientific Research from the Ministry of Education, Culture, Sports, Science, and Technology of Japan, grant \# 19390367.

\section{References}

I. Parkin DM, Whelan SL, Ferlay J, Teppo L, Thomas DB: Cancer Incidence in Five Continents Lyon: IARC; 2002.

2. Sorlie T, Tibshirani R, Parker J, Hastie T, Marron JS, Nobel A, Deng S, Johnsen H, Pesich R, Geisler S, et al.: Repeated observation of breast tumor subtypes in independent gene expression data sets. Proc Natl Acad Sci USA 2003, I 00:84 I 8-8423.

3. Cheang MC, Voduc D, Bajdik C, Leung S, McKinney S, Chia SK, Perou CM, Nielsen TO: Basal-like breast cancer defined by five biomarkers has superior prognostic value than triple-negative phenotype. Clin Cancer Res 2008, I 4:1368-1376.

4. Nielsen TO, Hsu FD, Jensen K, Cheang M, Karaca G, Hu Z, Hernandez-Boussard T, Livasy C, Cowan D, Dressler L, et al.: Immunohistochemical and clinical characterization of the basal-like subtype of invasive breast carcinoma. Clin Cancer Res 2004, 10:5367-5374.

5. Diaz LK, Cryns VL, Symmans WF, Sneige N: Triple negative breast carcinoma and the basal phenotype: from expression profiling to clinical practice. Adv Anat Pathol 2007, I 4:4 I 9-430.

6. Rakha EA, El-Sayed ME, Green AR, Lee AH, Robertson JF, Ellis IO: Prognostic markers in triple-negative breast cancer. Cancer 2007, 109:25-32.

7. Kim MJ, Ro JY, Ahn SH, Kim HH, Kim SB, Gong G: Clinicopathologic significance of the basal-like subtype of breast cancer: $a$ comparison with hormone receptor and Her2/neu-overexpressing phenotypes. Hum Pathol 2006, 37:1217-1226.

8. Turner NC, Reis-Filho JS, Russell AM, Springall RJ, Ryder K, Steele D, Savage K, Gillett CE, Schmitt FC, Ashworth A, Tutt AN: BRCAI dysfunction in sporadic basal-like breast cancer. Oncogene 2007, 26:2126-2132

9. Yang Q, Sakurai T, Mori I, Yoshimura G, Nakamura M, Nakamura Y, Suzuma T, Tamaki T, Umemura T, Kakudo K: Prognostic significance of BRCAI expression in Japanese sporadic breast carcinomas. Cancer 200I, 92:54-60.

10. Matros E, Wang ZC, Lodeiro G, Miron A, Iglehart JD, Richardson AL: BRCAI promoter methylation in sporadic breast tumors: relationship to gene expression profiles. Breast Cancer Res Treat 2005, $91: 179-186$

11. Elston CW, Ellis IO: Pathological prognostic factors in breast cancer. I. The value of histological grade in breast cancer: experience from a large study with long-term follow-up. Histopathology 1991, 19:403-410.

12. Harvey JM, Clark GM, Osborne CK, Allred DC: Estrogen receptor status by immunohistochemistry is superior to the ligandbinding assay for predicting response to adjuvant endocrine therapy in breast cancer. J Clin Oncol 1999, 17:1474-|1481.

13. Kandioler-Eckersberger D, Ludwig C, Rudas M, Kappel S, Janschek E, Wenzel C, Schlagbauer-Wadl H, Mittlbock M, Gnant M, Steger G, Jakesz R: TP53 mutation and p53 overexpression for predic- tion of response to neoadjuvant treatment in breast cancer patients. Clin Cancer Res 2000, 6:50-56.

14. Angele S, Treilleux I, Taniere P, Martel-Planche G, Vuillaume M, Bailly C, Bremond A, Montesano R, Hall J: Abnormal expression of the ATM and TP53 genes in sporadic breast carcinomas. Clin Cancer Res 2000, 6:3536-3544.

15. Yamashita H, Nishio M, Toyama T, Sugiura H, Zhang Z, Kobayashi S, Iwase $\mathrm{H}$ : Coexistence of HER2 over-expression and p53 protein accumulation is a strong prognostic molecular marker in breast cancer. Breast Cancer Res 2004, 6:R24-30.

16. Malzahn K, Mitze M, Thoenes M, Moll R: Biological and prognostic significance of stratified epithelial cytokeratins in infiltrating ductal breast carcinomas. Virchows Arch 1998, 433:1 I9-129.

17. Bhargava R, Gerald WL, Li AR, Pan Q, Lal P, Ladanyi M, Chen B: EGFR gene amplification in breast cancer: correlation with epidermal growth factor receptor MRNA and protein expression and HER-2 status and absence of EGFR-activating mutations. Mod Pathol 2005, 18:1027-1033.

18. Endo K, Konishi A, Sasaki H, Takada M, Tanaka H, Okumura M, Kawahara $M$, Sugiura $H$, Kuwabara $Y$, Fukai I, et al.: Epidermal growth factor receptor gene mutation in non-small cell lung cancer using highly sensitive and fast TaqMan PCR assay. Lung Cancer 2005, 50:375-384.

19. Zhao X, Li C, Paez JG, Chin K, Janne PA, Chen TH, Girard L, Minna J, Christiani $D$, Leo $C$, et al.: An integrated view of copy number and allelic alterations in the cancer genome using single nucleotide polymorphism arrays. Cancer Res 2004, 64:3060-307I.

20. Moroni M, Veronese S, Benvenuti S, Marrapese G, Sartore-Bianchi A, Di Nicolantonio F, Gambacorta M, Siena S, Bardelli A: Gene copy number for epidermal growth factor receptor (EGFR) and clinical response to antiEGFR treatment in colorectal cancer: a cohort study. Lancet Oncol 2005, 6:279-286.

21. Takano T, Ohe Y, Sakamoto H, Tsuta K, Matsuno Y, Tateishi U, Yamamoto S, Nokihara H, Yamamoto N, Sekine I, et al.: Epidermal growth factor receptor gene mutations and increased copy numbers predict gefitinib sensitivity in patients with recurrent non-small-cell lung cancer. J Clin Oncol 2005, 23:6829-6837.

22. Toyama T, Iwase H, Watson P, Muzik H, Saettler E, Magliocco A, DiFrancesco L, Forsyth P, Garkavtsev I, Kobayashi S, Riabowol K: Suppression of ING I expression in sporadic breast cancer. Oncogene 1999, 18:5187-5193.

23. Paez JG, Janne PA, Lee JC, Tracy S, Greulich H, Gabriel S, Herman P, Kaye FJ, Lindeman N, Boggon T], et al.: EGFR mutations in lung cancer: correlation with clinical response to gefitinib therapy. Science 2004, 304:1497-1500.

24. Sasaki H, Endo K, Konishi A, Takada M, Kawahara M, luchi K, Matsumura $A$, Okumura $M$, Tanaka $H$, Kawaguchi T, et al:: EGFR Mutation status in Japanese lung cancer patients: genotyping analysis using LightCycler. Clin Cancer Res 2005, I I:2924-2929.

25. Early Breast Cancer Trialists' Collaborative Group (EBCTCG): Effects of chemotherapy and hormonal therapy for early breast cancer on recurrence and 15-year survival: an overview of the randomised trials. Lancet 2005, 365:1687-1717.

26. Smith I, Procter M, Gelber RD, Guillaume S, Feyereislova A, Dowsett M, Goldhirsch A, Untch M, Mariani G, Baselga J, et al.: 2-year followup of trastuzumab after adjuvant chemotherapy in HER2positive breast cancer: a randomised controlled trial. Lancet 2007, 369:29-36.

27. Romond EH, Perez EA, Bryant J, Suman VJ, Geyer CE Jr, Davidson NE, Tan-Chiu E, Martino S, Paik S, Kaufman PA, et al.: Trastuzumab plus adjuvant chemotherapy for operable HER2-positive breast cancer. N Engl J Med 2005, 353:1673-1684.

28. Mitsudomi T, Kosaka T, Endoh H, Horio Y, Hida T, Mori S, Hatooka S, Shinoda M, Takahashi T, Yatabe Y: Mutations of the epidermal growth factor receptor gene predict prolonged survival after gefitinib treatment in patients with non-small-cell lung cancer with postoperative recurrence. J Clin Oncol 2005, 23:2513-2520.

29. Hirsch FR, Varella-Garcia M, Cappuzzo F, McCoy J, Bemis L, Xavier AC, Dziadziuszko R, Gumerlock P, Chansky K, West H, et al.: Combination of EGFR gene copy number and protein expression predicts outcome for advanced non-small-cell lung cancer patients treated with gefitinib. Ann Oncol 2007, 18:752-760.

30. Sasaki H, Endo K, Okuda K, Kawano O, Kitahara N, Tanaka H, Matsumura A, luchi K, Takada M, Kawahara M, et al.: Epidermal growth 
factor receptor gene amplification and gefitinib sensitivity in patients with recurrent lung cancer. J Cancer Res Clin Oncol 2008, 134:569-577.

31. Ma Y, Lespagnard L, Durbecq V, Paesmans M, Desmedt C, GomezGaldon M, Veys I, Cardoso F, Sotiriou C, Di Leo A, et al.: Polysomy 17 in HER-2/neu status elaboration in breast cancer: effect on daily practice. Clin Cancer Res 2005, I I:4393-4399.

32. Pinter F, Papay J, Almasi A, Sapi Z, Szabo E, Kanya M, Tamasi A, Jori $\mathrm{B}$, Varkondi E, Moldvay J, et al.: Epidermal growth factor receptor (EGFR) high gene copy number and activating mutations in lung adenocarcinomas are not consistently accompanied by positivity for EGFR protein by standard immunohistochemistry. J Mol Diagn 2008, 10:160-168.

33. Rakha EA, Reis-Filho JS, Ellis IO: Basal-like breast cancer: a critical review. J Clin Oncol 2008, 26:2568-258I.

34. Turner N, Tutt A, Ashworth A: Hallmarks of 'BRCAness' in sporadic cancers. Nat Rev Cancer 2004, 4:8I4-8I9.

35. Liu S, Ginestier C, Charafe-Jauffret E, Foco H, Kleer CG, Merajver SD, Dontu G, Wicha MS: BRCAI regulates human mammary stem/progenitor cell fate. Proc Natl Acad Sci USA 2008 105:1680-1685

36. Narod SA, Foulkes WD: BRCAI and BRCA2: 1994 and beyond. Nat Rev Cancer 2004, 4:665-676.

37. Schreiber V, Dantzer F, Ame JC, de Murcia G: Poly(ADP-ribose): novel functions for an old molecule. Nat Rev Mol Cell Biol 2006 , 7:517-528.

38. Farmer H, McCabe N, Lord CJ, Tutt AN, Johnson DA, Richardson TB, Santarosa M, Dillon KJ, Hickson I, Knights C, et al:: Targeting the DNA repair defect in BRCA mutant cells as a therapeutic strategy. Nature 2005, 434:917-92I.

39. Haffty BG, Yang Q, Reiss M, Kearney T, Higgins SA, Weidhaas J, Harris $L$, Hait W, Toppmeyer D: Locoregional relapse and distant metastasis in conservatively managed triple negative earlystage breast cancer. J Clin Oncol 2006, 24:5652-5657.

40. Dent R, Trudeau M, Pritchard KI, Hanna WM, Kahn HK, Sawka CA, Lickley LA, Rawlinson E, Sun P, Narod SA: Triple-negative breast cancer: clinical features and patterns of recurrence. Clin Cancer Res 2007, I 3:4429-4434.

41. Liedtke C, Mazouni C, Hess KR, Andre F, Tordai A, Mejia JA, Symmans WF, Gonzalez-Angulo AM, Hennessy B, Green M, et al. Response to neoadjuvant therapy and long-term survival in patients with triple-negative breast cancer. J Clin Oncol 2008 26: $|275-| 28 \mid$

42. Tischkowitz M, Brunet JS, Begin LR, Huntsman DG, Cheang MC, Akslen LA, Nielsen TO, Foulkes WD: Use of immunohistochemical markers can refine prognosis in triple negative breast cancer. BMC Cancer 2007, 7:134.

43. Carey LA, Dees EC, Sawyer L, Gatti L, Moore DT, Collichio F, Ollila DW, Sartor Cl, Graham ML, Perou CM: The triple negative paradox: primary tumor chemosensitivity of breast cancer subtypes. Clin Cancer Res 2007, 13:2329-2334.

44. Rouzier R, Perou CM, Symmans WF, Ibrahim N, Cristofanilli M, Anderson K, Hess KR, Stec J, Ayers M, Wagner P, et al.: Breast cancer molecular subtypes respond differently to preoperative chemotherapy. Clin Cancer Res 2005, I I:5678-5685.

\section{Pre-publication history}

The pre-publication history for this paper can be accessed here:

http://www.biomedcentral.com/1471-2407/8/309/pre pub Publish with BioMed Central and every
scientist can read your work free of charge

"BioMed Central will be the most significant development for disseminating the results of biomedical research in our lifetime. "

Sir Paul Nurse, Cancer Research UK

Your research papers will be:

- available free of charge to the entire biomedical community

- peer reviewed and published immediately upon acceptance

- cited in PubMed and archived on PubMed Central

- yours - you keep the copyright
BioMedcentral 